THE NATURE OF SOGIAL WORK 


\title{
The Nature of Social Work
}

\author{
ZOFIA T. BUTRYM \\ Senior Lecturer in Social Work \\ London School of Economics and Political Science
}

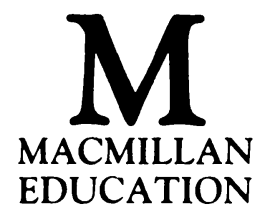


All rights reserved. No reproduction, copy or transmission of this publication may be made without written permission.

No paragraph of this publication may be reproduced, copied or transmitted save with written permission or in accordance with the provisions of the Copyright Act 1956 (as amended), or under the terms of any licence permitting limited copying issued by the Copyright Licensing Agency, 33-4 Alfred Place, London WC1E 7DP.

Any person who does any unauthorised act in relation to this publication may be liable to criminal prosecution and civil claims for damages.

First published 1976

Reprinted 1978, 1979, 1982, 1985, 1986, 1988

\section{Published by}

MACMILLAN EDUCATION LTD

Houndmills, Basingstoke, Hampshire RG21 2XS

and London

Companies and representatives

throughout the world

ISBN 978-0-333-19703-5 ISBN 978-1-349-15685-6 (eBook)

DOI 10.1007/978-1-349-15685-6 


\section{Contents}

Foreword vii

Introduction $\quad$ ix

1 The Problem of Identity in Social Work 1

2 Models of Social-Work Practice 15

3 The Place of Values in Social Work 40

4 The Place of Knowledge in Social Work 63

5 The Social-Work Process 81

6 Social Work and Society 105

7 Some Current Issues in Social Work and their

References 151

$\begin{array}{ll}\text { Index } & 163\end{array}$ 


\section{Foreword}

The views expressed in this book are the outcome of my thinking after twenty-five years in social work, first as a practitioner and later as a teacher. They inevitably reflect the totality of my experience, background and beliefs, and so, no doubt, my Polish origins, Christian upbringing and emotionally secure childhood will have contributed to my particular perspective.

I should like to pay tribute to all those who have influenced my professional development, whether at the L.S.E., the Institute of Medical Social Workers, the Tavistock Clinic, or in those social-work departments where I have been a student or have been employed. I owe special gratitude to Gwen Price and Enid Warren who have been of so much help to me both professionally and personally during my early years in this country. I am also indebted to colleagues and students, past and present, for all I have learnt from them, and to the many authors from whose writings I quote so extensively.

Last, I want to thank particularly those colleagues and friends who read chapters of the book at various stages of drafting, offered constructive criticism and gave me warm encouragement. Were I to mention their names the list would be long, and in a book expressing my personal views in a sometimes controversial context I thought anonymity might be preferred. I hope, therefore, that I shall be forgiven for not referring to them individually. One exception, however, that must be made are my thanks to Anne Deakins for her willingness and care in typing the manuscript and for her patience in deciphering my handwriting - renowned for its illegibility.

Z.T.B. 


\section{Introduction}

The fact that it was considered necessary to devote a book to a discussion of the nature of social work is in itself worthy of attention. The nature of most of the other professions and occupations, such as those of the law, medicine, nursing, teaching and architecture, is far less ambiguous, and so the need for such clarification is less apparent.

The special position of social work in this respect can be put down to two interrelated factors. Social work is not only a relatively young profession but it is also one which derives more directly and more substantially from the particular society of which it is a part than is the case with other professions. Hence its functions and its modes of operation are substantially dependent on existing social structures and are to a great extent affected by the various processes of change within them. In addition, the preoccupation of social work with people and with their social circumstances creates its main occupational risk - that of a lack of specificity, of an inherent ambiguity - which makes it particularly prone to changes and fluctuations, not all of which are necessarily consistent or logical.

This ambiguity and ready exposure to external influences lays social work open to different interpretations regarding its nature and functions, and also encourages the expression of strongly held opinions on these matters not only on the part of social workers but also by others. Thus, on the one hand, there is a tendency for some people to view social work as little more than a matter of 'kindness of heart' and of 'common sense', thus potentially an opening for all men and women of goodwill. This conception of social work usually carries with it a marked reluctance to credit professional social work with any special or even additional expertise. In contrast, social work has been vested in recent years with increasing power and responsibility in the realm of 
containment, control and alleviation of some of the major problems facing contemporary society. The granting of such power and responsibility by society to social work implies a degree of confidence in its knowledge and capabilities which even many social workers would consider excessive.

This book will not attempt a historical review of social work because that is a task in its own right. However, where appropriate, references will be made to past trends and to their relevance to current issues. This will inevitably include criticisms of some of the writings about social work in the past when they present a simplistic or a distorted picture of the historical perspective. A good comprehensive history of British social work still waits to be written.

In The Nature of Social Work I shall try to focus on those characteristics of social work which make up its separate identity. I shall argue that this identity is largely derived from the nature of the relationship between certain value-based objectives and a unique amalgam of instrumental values, applied knowledge, practical skills and specific social context which constitutes the means by which these objectives are translated into action.

The book will therefore examine the nature of the objectives in social work, its value base, the sources of knowledge upon which social workers draw, the range of skills by means of which the values and the knowledge are made operational, and the effects of organisational settings upon social workers' functions. In addition, given the fact that social work is a social institution, and one which currently is vested with considerable importance in British society, the following additional structural issues will also be considered. What place does social work hold as an agent of both social caring and social control? What is the nature of the relationship between social work and the other social services? What are the implications for society and for social work of its expanding functions? Is there a need to draw more clear-cut boundaries within which social work is to operate and, if so, what should these be?

No great claims are made for originality in the approach to all these questions, and no ready solutions will be offered to the problems discussed. At the same time, no apologies are offered for the many expressions of personal viewpoint on the issues under consideration, and for a polemical rather than a 'purely' academic approach to some of them. This is because underlying the whole book is my interest in 
and commitment to social work as a humane and civilised form of expressing the responsibility of human beings for each other which would have invalidated any appearance of neutrality on my part. This is especially so in that, as will be argued throughout, social work is a 'value-ridden' activity, and therefore any serious discussion of it must incorporate moral issues.

A strong incentive for attempting this piece of writing was my growing realisation that whilst a large number of books about social work were coming from the North American continent, this was not being similarly matched by British writing, with the consequence that many inappropriate deductions were being drawn from the American scene about British social work, adding further to the widespread confusion about its nature. In the last couple of decades a number of useful books by British authors dealing with particular aspects of social work have appeared, but what remained lacking was a more comprehensive look. The only grounds on which I can hope that this work may fill an existing gap is that it attempts to present a holistic view of social work, a composite picture of all of its many interrelated and interacting parts which is difficult to convey when discussion focuses on any one or several of these parts.

The Nature of Social Work is not a textbook. It is not detailed enough for this purpose and pays relatively little attention to techniques as opposed to the more general considerations of a philosophical nature a focus which is reflected in the title. For this reason, no attempt was made to provide a comprehensive bibliography, and the references quoted have been selected on the basis of their relevance to the discussion of the various themes in the book.

I realise that to attempt an approach to social work on these more comprehensive lines is to undertake a demanding task with a limited equipment. My justification for such an endeavour is not in assuming I have answers to the dilemmas posed but in my strong wish to encourage both social workers and others with an interest in social work to give time and attention to their serious consideration. 